DOI: $10.17951 / \mathrm{m} \cdot 2018.3 \cdot 47-65$

\begin{tabular}{lcr}
\hline & ANNALES \\
& UNIVERSITATIS MARIAE CURIE-SKLODOWSKA & \\
LUBLIN - POLONIA & \\
VOL. III & SECTIO M & 2018 \\
\hline
\end{tabular}

\author{
Sebastian Kubas \\ University of Silesia in Katowice \\ sebastian.kubas@us.edu.pl \\ ORCID ID: http://orcid.org/0000-0002-7609-4002 \\ Anna Czyż \\ University of Silesia in Katowice \\ annaczyz@us.edu.pl \\ ORCID ID: http://orcid.org/0000-0003-2534-0733
}

\title{
From a Liberal Opposition Party to a Right-Wing Party of Power. Three Decades of the Hungarian Fidesz (1988-2018)
}

\section{Introduction}

The repeated successes of the right-wing Fidesz group - Hungarian Civic Union (Hungarian: Fiatal Demokraták Szövetsége - Magyar Polgári Szövetség, Fidesz), which last almost a decade now, are the result of a combination of various factors. Their genesis and essence have a multidimensional character. It should be noted that while the first electoral victory in 2010 could have been largely a consequence of the discrediting of the Hungarian Socialist Party (Hungarian: Magyar Szocialista Párt, MSzP) in the eyes of voters and the entrustment of alternative power to Fidesz, maintaining the dominant position in the political and party system in 2014 and 2018 required taking different measures. After 2010, Fidesz had to carry out activities aimed at maintaining power, and utilized both the functional structure of Hungarian state authorities, as well as the mass media for this end.

The objective of the present article is to analyze three Fidesz electoral successes in Hungary over the years 2010-2018 in the light of three decades of 
existence of this party. This will require referring to the situation in the periods preceding the last three parliamentary elections, discussing the results of Fidesz's parliamentary elections as well as post-electoral consequences for Fidesz and its activities in the field of state policy, including measures taken to maintain power.

In the methodological and theoretical dimension, we will refer to theories regarding the institutionalization of political parties, as well as concepts relating to the definition of political parties, based on an organizational criterion ${ }^{1}$. The research methods utilized by us include: analysis and synthesis of data, including legal acts and the statistical method.

The thesis of the article is related to the claim that in 2010-2018, Fidesz skillfully used both previous experience from its first government period (19982002) as well as legal and propaganda measures introduced after 2010 in order to obtain subsequent re-elections in the National Assembly elections.

Before starting the research, two basic questions arose that we will attempt to answer during the research process: 1) How did Viktor Orbán and his party achieve electoral success in 2010? and 2) What mechanisms used by Fidesz were applied in 2010-2018 to remain in power?

The present article consists of four interrelated parts, the first of which concerns the genetic determinants associated with the Fidesz situation before 2010. The three subsequent chapters undertake the 2010, 2014 and 2018 pre-election and post-election analysis, when Fidesz obtained the support of the Hungarian electorate, allowing it to exercise power in the state.

Fidesz: 1988-2010

Fidesz was founded on 30 March 1988. It was created by a group of people connected with the college of the Faculty of Law at the Eötvös Loránd University in Budapest ${ }^{2}$. The founders included Viktor Orbán, Lajos Simicska, Gábor Fodor, László Kövér, János Áder, József Szájer. The organization was illegal at that time, and adopted a principle that the upper age limit for its member would be 35 years $^{3}$. In 1989, on the conditions set by the socialist, undemocratic regime, the Hungarian authorities agreed to the legalization of opposition organizations, granting them the form of associations. Therefore, in the result of adoption of an

1 See: M. Chmaj, W. Sokól, M. Żmigrodzki, Teoria partii politycznych, Wydawnictwo Morpol, Lublin 1999; R. Herbut, Teoria i praktyka funkcjonowania partii politycznych, Wydawnictwo Uniwersytetu Wrocławskiego, Wrocław 2002.

2 J. Debreczeni, Viktor Orbán. Jeden obóz, jeden sztandar, jeden wódz, Wydawnictwo Akurat, Warszawa 2015, pp. 35-46.

3 Ibidem, pp. 1-46. 
administrative system that granted the state authorities the possibility of strict control of political associations and the rationing of their activities, Fidesz initiated its legal activities ${ }^{4}$. The young activists of Fidesz negatively assessed the communist period, and therefore demanded that it should be replaced by a democratic regime. They expressed this in their first political program adopted in autumn 1988. It was there that they wrote about the need to reform the education system, to separate the state authorities from the communist party, to adopt changes in the economy consisting in the introduction of free market principles ${ }^{5}$.

With reference to the concept of Marek Sobolewski, we can say that genetically, in organizational terms, Fidesz appeared as an extra-parliamentary party, because its primary goal was not electoral struggle, but a decisive opposition to communism. They also adopted a formula of a direct party, that could be accessed by joining a field structure of the party. Let us add that during its initial development the party elaborated a strategy of a strong articulation organization, that is, it normalized the activity and structure in its statute ${ }^{6}$.

As mentioned above, Fidesz appeared as a new opposition organization during the liberalization of the undemocratic communist regime in Hungary together with two other illegal entities: the Hungarian Democratic Forum (Hungarian: Magyar Demokrata Fórum, MDF) and the Hungarian Union of Free Democrats (Hungarian: Szabad Demokraták Szövetsége, SzDSz). These organizations and the reactivating historical parties constituted a platform that denied the activities of the hegemonic group, the Hungarian Socialist Workers' Party (Hungarian: Magyar Szocialista Munkáspárt, MSzMP).

As a result of the deepening crisis of the state, the elite of power associated with the MSzMP offered negotiations to the opposition organizations, aiming at finding a way out of the impasse. Before the talks began, the opposition organized its own debates, held as part of a round table (Hungarian: Ellenzéki Kerekasztal, EKA). They were initiated on 22 March 1989 and Fidesz was one of the participants. As a result of the talks, the opposition decided to create a single core in relation to the MSzMP. However, as the future was to demonstrate, Fidesz broke from this informal deal. After the end of national negotiations, which took the form of a triangular table (Hungarian: Nemzeti Kerekasztal, NKA), it failed to sign the final act of 18 September 1989, thereby distancing the party

4 M. Chmaj, W. Sokół, M. Żmigrodzki, op. cit., p. 77.

5 Z. Ripp, Unity and Division. The Opposition Roundtable and Its Relation to the Communist Party, [in:] The Roundtable Talks of 1989: The Genesis of Hungarian Democracy, ed. A. Bozóki, Central European University Press, Budapest 2002, pp. 3-39.

6 M. Sobolewski, Partie i systemy partyjne świata kapitalistycznego, Państwowe Wydawnictwo Naukowe, Warszawa 1977, pp. 266-280. 
from the agreement that was to lead to the democratic transition. It was on its initiative that on 26 November 1989, a nationwide referendum was held, and the citizens were to decide on the severity of changes in the political system. Fidesz was convinced that the proposals of the triangular table are not radical enough, and therefore conciliatory in relation to MSzMP. The results of the referendum confirmed the correctness of Fidesz's position, and the Hungarians agreed with the proposals concerning, among others, indirect choice of the head of state, which rendered it difficult to elect a communist candidate for this position?

In the initial period of democratization, Fidesz adopted the formula of a liberal party, which was confirmed by its accession to the Liberal International in 1992. Due to the fact that another liberal party, the SzDSz was present in Hungary at that time, the possibility of obtaining a wider electorate with liberal views could not allow Fidesz to obtain satisfactory election results. This found its confirmation in the data from both the 1990 and the 1994 parliamentary elections. After the first free elections, Fidesz won $5.44 \%$ of voters' support, which translated into 21 seats. After the second free elections, it received $5.7 \%$ and 22 seats, respectively ${ }^{8}$. In the first two election campaigns, Fidesz emphasized the necessity of adopting Western European economic and political standards, limiting the role of the state, inspecting the members of clergy for their cooperation with communists, limiting the influence of religion on public life, development of a neutral education system ${ }^{9}$.

After a group of activists with liberal views headed by Gábor Fodor left the party in 1993, Orbán and the head management team decided to change the ideological profile of Fidesz. In the parliamentary elections of 1994, the rightwing MDF suffered a miserable defeat, partly paying for their leadership in the first non-communist government. Thus, Fidesz took steps to transform the party from a liberal into a right-wing group. In April 1995, they added the name Hungarian Civic Party (Hungarian: Magyar Polgári Párt) to the name. In addition, Fidesz signed cooperation agreements with several small right-wing parties. In 1997, the right wing of MDF concluded an agreement with Fidesz. The process that was initiated in 1993 turned out to be successful because in 1998, Fidesz

7 M. Podolak, Instytucja referendum w wybranych państwach Europy Środkowej $i$ Wschodniej (1989-2012), Wydawnictwo Uniwersytetu Marii Curie-Skłodowskiej, Lublin 2014, pp. 329-331.

${ }^{8}$ M. Barański, A. Czyż, S. Kubas, R. Rajczyk, Wybory, prawo wyborcze, systemy wyborcze w państwach Grupy Wyszehradzkiej, Wydawnictwo Uniwersytetu Śląskiego, Katowice 2016, p. $162,164$.

9 Z. Enyedi, The Role of Agency in Cleavage Formation, "European Journal of Political Research" 2005, Vol. 44(5), p. 703. 
won the first place in the parliamentary election. This meant the consolidation of this party within the conservative family of political parties ${ }^{10}$.

In the third election to the National Assembly (1998), Fidesz obtained 148 seats and $38.34 \%$ of votes ${ }^{11}$. Orbán became the head of the coalition government consisting of his party, MDF and the Independent Party of Smallholders, Workers of Agriculture and Citizens (Hungarian: Független Kisgazda-, Földmunkás- és Polgári Párt, FKgP). In its first government, Fidesz attempted to support small and medium-sized domestic enterprises, reduce taxes, and limit public debt. In relations with neighbouring countries, the government underlined the need to protect the rights of Hungarian minorities. However, taking control of the media and modifying the electoral law ${ }^{12}$ proved impossible.

During their first government, Fidesz was able to develop the tactics of behaviour associated with the clientelistic strategy that reached far beyond raising funds for operations from the state budget. The possibility of deriving financial resources from the budget of Hungary allowed for the construction and development of a clientele network based on granting lucrative provisions to distinguished members and supporters of Fidesz ${ }^{13}$.

In the 2002 election campaign, Fidesz, for the first time, had to defend its achievements against criticism of other parties taking part in the parliamentary elections. Even finishing first (188 seats, $48.7 \%$ of votes $\left.{ }^{14}\right)$ it was unable to form a government, following political arrangements of other parties. For the second time in history the Hungarian Socialist Party (Hungarian: Magyar Szocialista Párt, MSzP) agreed with the SzDSz on the construction of a coalition government, thus pushing Fidesz to the opposition.

Fidesz decided to use the next parliamentary term to introduce itself to the Hungarian public as a party protesting against the liberalization of the state and power being exercised by the former communist elite. Steps were also taken to strengthen cooperation with right-wing parties within a broad platform led by Fidesz, facilitated by the addition of a new part to the party's name in the form of the Hungarian Citizens' Union (Hungarian: Magyar Polgári Szövetség). In the 2006 election campaign, requests were put forward for lustration in the state, de-communization, and support for the domestic economic market ${ }^{15}$. However,

\footnotetext{
${ }^{10}$ R. Herbut, op. cit., pp. 174-179.

${ }^{11}$ M. Barański, A. Czyż, S. Kubas, R. Rajczyk, op. cit., p. 168.

${ }^{12}$ Ibidem, pp. 169-170.

${ }^{13}$ R. Herbut, op. cit., pp. 67-74.

${ }^{14}$ M. Barański, A. Czyż, S. Kubas, R. Rajczyk, op. cit., p. 170.

${ }^{15}$ V. Glied, From a Green Movement to a Party. The Effect of the Crisis and Democratic Movements in Hungary, "Politeja" 2014, No. 28.
} 
the fifth parliamentary election (2006) did not bring Fidesz success $(42.5 \%$ of votes, 164 seats $\left.^{16}\right)$ and it remained in opposition.

Several months after the election results were announced in 2006 and the social-liberal coalition was recreated, a recording from a MSzP party meeting was leaked to the media, on which the PM Ferenc Gyurcsány admitted that he concealed the information about the poor condition of the economy during the campaign from the Hungarian public, in order to secure re-election. The Hungarians were outraged, both by lack of information on the condition of their economy, and the lie of the prime minister. Serious riots broke out in the country. Fidesz joined the protest action demanding the dismissal of the prime minister, the government, and even new elections. Still, this never happened. Therefore, for the next four years, up to 2010, Fidesz took actions that were shedding light of a party on morality and ethics criticizing the government on it. Any cooperation with the government was refused. Fidesz's popularity came under test in the 2008 governmental referendum that concerned the introduction of tuition fees for universities and fees in the healthcare system. The ruling coalition decided to ask compatriots if they would be more inclined to pay due to the economic crisis. The turnout was over $50 \%$, of which $84.1 \%$ of citizens voted against increases. It meant that the legitimacy of power for MSzP and SzDSz was undermined, with the simultaneous success of Fidesz, which urged the Hungarians to oppose ${ }^{17}$.

\section{Victory: 2010}

In 2010, Fidesz entered the election campaign with the slogan "It's about time!", which was related to the willingness to settle the past, both from the period of 8-year rule of MSzP and SzDSz (2002-2010), as well as the earlier one, related to communism. Just months before the elections, Fidesz proposed some important changes in the political system. It criticized parliamentarism because the indirect form of representing the interests of society distorted the will of the whole. It also considered the possibility of strengthening the president's competences, which was connected with the possible takeover of this office in the future by Orbán. There was talk about the need to change the electoral system. However, the aforementioned issues of political changes were not underscored in the campaign, but only used in such a way as to demonstrate the party as a supporter of a modern

${ }^{16}$ M. Barański, A. Czyż, S. Kubas, R. Rajczyk, op. cit., p. 173.

${ }^{17}$ E. Rytkó, National Referenda in Hungary, 20.11.2018, http://www.aceeeo.org/sites/default/files/PDF/presentation_of_conference/2008/Referenda\%20in\%20Hungary_english.pdf [access: 20.11.2015]; M. Podolak, op. cit. pp. 367-369. 
approach to reforms in the state. An important issue raised in the campaign was the issue of Hungarian minorities. Fidesz believed that one should take into account the possibility of increasing the rights of Hungarians living outside the country, including those with foreign citizenship, but who feel Magyar. In the socio-economic dimension, Orbán's party had to refer to the economic crisis that continued for several years in Hungary. They proposed to increase state aid in the development of small and medium-sized indigenous enterprises in order to reduce the unemployment, which at that time hit the $11 \%$ rate. They also announced, that shall they win, they will introduce an additional tax on large-format stores and companies representing foreign interests ${ }^{18}$.

During the 2010 election campaign, Fidesz was very aggressive towards MSzP. It criticized the ruling party for bringing the country to an economic crisis and manipulating public opinion in 2006. Almost every thesis of the left was attacked, and favouring by media sought for. Activities of Lajos Simicski, who since the 1990s led various economic enterprises that brought Fidesz considerable profits, largely influenced the party's financial condition and its ability to develop and finance electoral campaign ${ }^{19}$.

Pre-election opinion polls indicated a huge advantage given to Fidesz. In March 2010, the Tárki public opinion centre estimated the support for Fidesz within $61 \%$, while Századvég - at $56 \%{ }^{20}$. The parliamentary elections were held on 11 (first round) and 25 April (second round) 2010. The turnout reached 64.38\% (first round) and 46.66\% (second round) ${ }^{21}$.

Fidesz joined the elections in coalition with the Christian Democratic People's Party (Hungarian: Kereszténydemokrata Néppárt, KDNP). The coalition won $53.64 \%$ of votes in single-mandate constituencies and $52.73 \%$ in multi-mandate constituencies. This recalculated to seats meant that Fidesz and KDNP received 263, i.e. $67.88 \%$ of the total number of parliamentary mandates. As a result, the new government coalition had over $2 / 3$ of seats in the Hungarian National Assembly.

${ }^{18}$ S. Kubas, Sukcesy wyborcze Fidesz-MSP i ich wptyw na konsolidacje prawicowych rzadów na Węgrzech, [in:] Polskie wybory 2014-2015. Kontekst krajowy i międzynarodowy: przebieg rywalizacji, konsekwencje polityczne, t. 2, red. M. Kolczyński, Wydawnictwo Uniwersytetu Śląskiego, Katowice 2017, pp. 341-350.

${ }^{19}$ J. Debreczeni, op. cit., pp. 89-110.

${ }^{20}$ Tárki public opinion research centre, https://www.tarki.hu/ [access:15.11.2018]; Századvég public opinion research centre, https://szazadveg.hu/hu [access: 15.11.2018].

${ }^{21}$ Nemzeti Választási Iroda. Országgyülési választások Magyarországon 2010, http://www. valasztas.hu/en/parval2010/298/298_0_index.html [access: 9.02.2016]; NSD. European Election Database. Hungary: Parliamentary Elections 2010, http://eed.nsd.uib.no/webview/index.jsp? study=http://129.177.90.166:80/obj/fStudy/HUPA1990_Display\&mode =cube\&v=2\&cube=ht tp://129.177.90.166:80/obj/fCube/HUPA1990_Display_C1\&top=yes [access: 9.02.2016]. 
Table 1. The results of the 2010 National Assembly elections in Hungary

\begin{tabular}{|c|c|c|c|c|c|c|c|c|c|}
\hline \multirow[b]{2}{*}{ Political parties } & \multicolumn{3}{|c|}{$\begin{array}{c}\text { Single-member } \\
\text { constituencies }\end{array}$} & \multicolumn{3}{|c|}{ Larger constituencies } & \multirow{2}{*}{ 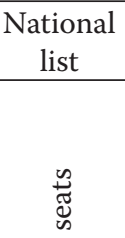 } & \multicolumn{2}{|c|}{ Total } \\
\hline & 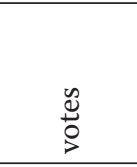 & 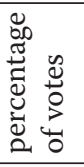 & 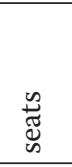 & $\stackrel{\substack{0 \\
0}}{>}$ & 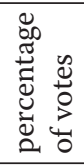 & 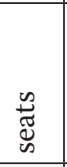 & & 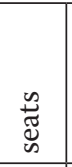 & 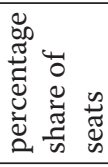 \\
\hline Fidesz-KDNP & $2,743,626$ & 53.64 & 173 & $2,706,292$ & 52.73 & 87 & 3 & 263 & 67.88 \\
\hline MSzP & $1,088,374$ & 21.27 & 2 & 990,428 & 19.3 & 28 & 29 & 59 & 15.28 \\
\hline Jobbik & 836,774 & 16.36 & 0 & 855,436 & 16.7 & 26 & 21 & 47 & 12.18 \\
\hline LMP & 259,220 & 5.07 & 0 & 383,876 & 7.50 & 5 & 11 & 16 & 4.15 \\
\hline Other parties & 152,874 & 3.72 & 0 & 196,499 & 3.80 & 0 & 0 & 0 & 0 \\
\hline Total & $5,114,570$ & 100 & 176 & $5,132,531$ & 100 & 146 & 64 & 386 & 100 \\
\hline
\end{tabular}

Source: Authors' own elaboration based on F. Grotz, L. Hubai, Hungary, [in:] Elections in Europe. A Data Book, eds. D. Nohlen, P. Stöver, Nomos, Baden-Baden 2010, p. 873 ff; Nemzeti Választási Iroda. Országgyülési választások Magyarországon 2010, http://www.valasztas.hu/en/parval2010/index.html [access: 09.11.2018].

Having such a large potential of seats in the parliament gave Fidesz legitimacy to undertake reforms in the sphere of the system and the economy. However, as the future was about to demonstrate, the scale of these changes and the way they were carried out went far beyond the method of democratization developed and applied for the past two decades.

The announcement of profound political and economic changes was reflected in the Declaration of National Cooperation, which the Hungarian parliament adopted already in April 201022. It announced the emergence of a new political and economic system. As a result of implementation of the announced changes, a year later, the Hungarian National Assembly adopted the new Constitution (18 April 2011). It left a parliamentary-cabinet model of relations between the highest organs of state power, but the scope of prime minister's competences was increased, and the competences of executive power in relation to state institutions. First of all, the freedom of the Constitutional Tribunal was limited, the scope of decentralization of state power was reduced, taking away some of the competences of the local self-government. The ideological and axiological dimension has been redefined, as the Constitution clearly resigned from the

${ }^{22}$ System Wspótpracy Narodowej, http://jezwegierski.blox.pl/2010/07/System-Wspolpracy -Narodowej.html [access: 21.11.2018]. 
appreciation of the principles of liberal democracy in favour of emphasizing the primacy of the conservative and national worldview ${ }^{23}$.

The electoral law was reformed, introducing significant simplifications of procedures related to voting and recalculation of votes to seats, replacing the three-level allocation of mandates with just two levels. On the other hand, a new division of the districts was introduced, and Hungarians living outside the country and holding dual citizenship were also allowed to participate in the elections. These last two moves were introduced as part of a tactic for guaranteeing greater support for Fidesz ${ }^{24}$.

During the 2010-2014 term, Fidesz took over control of many of the mass media, both by adopting laws in this respect, and buying these that remained in hands of the opposition to that date ${ }^{25}$. In the economic sphere, the tax on medium-sized and small enterprises was lowered, the tax on large corporations was increased, private pension funds were liquidated, and the scope of state control over the banking system and the power industry was broadened ${ }^{26}$.

It should be pointed out that the recovery of power after eight years of break and its exercise in the period 2010-2014 has consolidated the Fidesz profile based on the principles of patronage and clientelism. Fidesz returned to the tactics of filling important positions in the state with people supporting it and removing these who did not support its rule. We must, however, note that the very scale of this phenomenon and the way it was carried out were more radical and thorough than in the years 1998-2002. It was also evident that, entering the second decade of existence, Fidesz became a personal party ${ }^{27}$ in which Orbán uses interpersonal relations in order to preserve power in the party and also to maintain in the position of the head of government as long as possible. Fidesz operates based on the strong leadership of Orbán, who tries to maintain the conviction that without him the party, but also the state, will not be able to function properly, as long as possible.

${ }^{23}$ S. Kubas, Negacja dorobku i zdobyczy węgierskiej demokratyzacji po 2010 roku, „Studia Politologiczne" 2018, Vol. 47, pp. 119-124.

${ }^{24}$ S. Kubas, Zmiany w prawie wyborczym $w$ kontekście przeobrażeń ustrojowych na Węgrzech po 2011 roku, „Przegląd Politologiczny” 2017, nr 1, pp. 143-155.

${ }^{25}$ Wegry. Fidesz zdobywa nowe media publiczne, Analizy OSW, http://www.osw.waw.pl/pl/ publikacje/best/2010-08-04/wegry-fidesz-zdobywa-media-publiczne [access: 13.04.2012].

${ }^{26}$ A. Sadecki, Państwo stanu wyższej konieczności. Jak Orbán zmienit Wegry, „Punkt Widzenia" 2014, nr 41, p. 11.

${ }^{27}$ R. Herbut, op. cit., pp. 74-75. 


\section{Re-election: 2014}

The next parliamentary elections in Hungary, which ended with the victory of Fidesz, took place on 6 April 2014. The turnout in these elections was $61.73 \%{ }^{28}$. They were conducted based on the provisions of the new electoral law adopted on 23 December $2011^{29}$. The electoral system did not change from the mixed system that was in force so far, but introduced many solutions that were beneficial for large parties. It reduced the number of deputies from 386 to 199 and by introducing the principle of normal majority in the majority segment, eliminated the necessity of a second round of voting if in the first round none of the candidates in the single-mandate constituency won more than half of valid votes. The Hungarian voter has two votes: one vote for a candidate in a single-mandate constituency, and the other for a candidate from the national party list. The ordinance also clarified the voting rules for Hungarian citizens living abroad, who were granted the electoral law by the new Hungarian Constitution of 2011, giving them the opportunity to vote for candidates from the national party list. This procedure extended the electorate to a large part of Hungarians living abroad, who, as shown by the collected data, constituted the electorate of mainly the ruling Fidesz party (130 thousand people voted in 2014) $)^{30}$. Fidesz turned out to be the clear winner of the election, with 133 seats of 199 in the new National Assembly, and Orbán became the prime minister for the third time. Three more parties joined the parliament: an alliance of opposition parties under the name of Unity (Hungarian: Összefogás), which included the Hungarian Socialist Party (38 seats in total), Jobbik, that is, the Movement for a Better Hungary with 23 seats, and the Politics Can Be Different (Hungarian: Lehet Más a Politika!, LMP) with 5 seats.

In this term, the government of Orbán faced a serious internal and European issue in form of the migration crisis, which appeared in 2015, and was associated with a large influx of refugees from different parts of the world. Hungary became one of the European countries that became mostly affected by the crisis, as it is located on the shortest route for refugees and migrants from the Middle East, for whom the destination was mainly Germany (according to available data from the

${ }^{28}$ Hungarian Election Office, http://www.valasztas.hu/dyn/pv14/szavossz/en/napind_e. html [access: 22.11.2018].

29 A. Sadecki, Wegry Orbána: konstytucyjna konsolidacja władzy, Analizy OSW, 04.01.2012, https://www.osw.waw.pl/pl/publikacje/analizy/2012-01-04/wegry-orbana-konstytucyjna-konsolidacja-wladzy [access: 22.11.2018].

${ }^{30}$ A. Sadecki, Wybory na Wegrzech: potwierdzenie dominacji Viktora Orbána, Analizy OSW, 11.04.2018, https://www.osw.waw.pl/pl/publikacje/analizy/2018-04-11/wybory-na-wegrzech-potwierdzenie-dominacji-viktora-orbana [access: 22.11.2018]. 
beginning of 2015 to mid-September 2015, over 190 thousand illegal migrants crossed the Serbian-Hungarian border) ${ }^{31}$. This was the reason why the Hungarian authorities decided to tighten the regulations on illegal border crossing and construct a barbed-wire fence on the Hungarian-Serbian border, which was criticized by the European Union and changed the migration routes and trail ${ }^{32}$.

Table 2. The results of the 2014 National Assembly elections in Hungary

\begin{tabular}{|c|c|c|c|c|c|c|c|c|}
\hline \multirow[b]{2}{*}{ Political parties } & \multicolumn{3}{|c|}{ Single-member constituencies } & \multicolumn{3}{|c|}{ The national list } & \multicolumn{2}{|c|}{ Total } \\
\hline & $\stackrel{\substack{0 \\
0}}{3}$ & 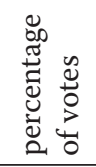 & 芯 & 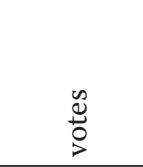 & 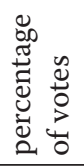 & $\begin{array}{l}\tilde{D} \\
\stackrel{\varpi}{\varpi} \\
\ddot{\infty}\end{array}$ & 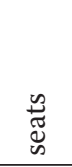 & 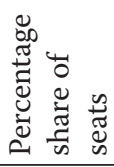 \\
\hline Fidesz-KDNP & $2,165,342$ & 44.87 & 96 & $2,264,780$ & 44.9 & 37 & 133 & 66.8 \\
\hline $\begin{array}{l}\text { MSzP-Együtt-D- } \\
\text { K-PM-MLP }\end{array}$ & $1,317,879$ & 25.57 & 10 & $1,290,806$ & 25.6 & 28 & 38 & 19.1 \\
\hline Jobbik & $1,000,637$ & 20.22 & 0 & $1,020,476$ & 20.2 & 23 & 23 & 11.6 \\
\hline LMP & 244,191 & 5.34 & 0 & 269,414 & 5.3 & 5 & 5 & 2.5 \\
\hline Other parties & 180,559 & 4 & 0 & 201,887 & 4 & 0 & 0 & 0 \\
\hline Total & $4,908,608$ & 100 & 106 & $5,047,363$ & 100 & 93 & 199 & 100 \\
\hline
\end{tabular}

Source: Authors' own elaboration based on: Hungarian Election Office, http://www.valasztas.hu/dyn/ pv14/szavossz/en/orszlist_e.html [access: 15.11.2018].

In Hungary, the decisive stance of Prime Minister Orbán in the face of a wave of refugees helped Fidesz to overcome the crisis of support and consolidate as the leader of opinion polls, and the migration crisis dominated the Hungarian public debate, pushing aside other topics as the prime rhetoric of the Prime Minister was in line with social moods that were clearly anti-immigrant. An important move by the Hungarian authorities was to order a nationwide referendum aimed at strengthening Hungary's position in the European Union in the debate on the migration crisis. The referendum held on 2 October 2016 resulted in $98 \%$ of Hungarians who cast a valid vote replied negatively to the question: "Do you want the European Union to decide, without the consent of the Hungarian Parliament, that people other than those with Hungarian

${ }^{31}$ M. Gniazdowski, M. Jarosiewicz, Wegierska odstona kryzysu migracyjnego, Analizy OSW, 9.09.2015, https://www.osw.waw.pl/pl/publikacje/analizy/2015-09-09/wegierska-odslona-kryzysu -migracyjnego [access: 3.11.2018].

${ }^{32}$ A. Sadecki, Wegry domknęty granicę z Serbia, Analizy OSW, 16.09.2015, https://www.osw. waw.pl/pl/publikacje/analizy/2015-09-16/wegry-domknely-granice-z-serbia [access: 11.11.2018].

33 Összefogás-Unity (alliance of opposition parties headed by the Hungarian Socialist Party). 
citizenship should be settled in Hungary?"34. It turned out, however, that the referendum was invalid, as only $40 \%$ of those entitled to vote took part in it, while, according to the new Hungarian Constitution of 2011, the turnout must amount to at least half of Hungarian citizens eligible to vote, so the criterion was not met ${ }^{35}$. The ruling Fidesz that initiated the referendum, encouraged people to vote "no", as did the opposition extreme right-wing Jobbik, with the remaining opposition parties encouraging the voters to boycott the referendum. "Prime Minister Orbán has failed to make the referendum «a matter of national importance» that would unite the society, which - according to surveys - is in the majority against the admission of migrants" ${ }^{36}$. The reasons for little social mobilization in the face of the referendum were to be found in the changing situation - the vote took place when the refugees have no longer been arriving in Hungary for a year. On the one hand, this was due to the construction of fence on the borders with Serbia and Croatia, which effectively stopped the flow of refugees and changed the migration routes to another direction, and on the other hand, a result of the agreement signed in March 2016 between the European Union and Turkey, and relieving migratory pressure on Europe. Therefore, the result of the referendum held in Hungary did not bring the expected propaganda success to its rulers. Fidesz's referendum campaign matched the rhetoric of tough opposition to the European Commission and the "European elite", which Orbán applied since seizing power in 2010. Migration policy became another area, where the Prime Minister of Hungary demonstrates the public that he is a defender of national interests in the European Union, referring to "the historical tradition of the resistance of the Hungarians against the will imposed on them from outside" 37 .

During the reign of the third government formed with participation of Fidesz, the "stop Soros" campaign became an extremely important area of the authorities' activities - that is how the changes in law against institutions related to the financier George Soros began to be described. In 2017, this campaign began with changes to the Central European University (CEU), which was funded by Soros in Budapest, and Soros himself was portrayed in the media as

${ }^{34}$ A. Sadecki, Dyskusyjny sukces Orbána - wyniki referendum migracyjnego na Wegrzech, Analizy OSW, 4.10.2016, https://www.osw.waw.pl/pl/publikacje/analizy/2016-10-04/dyskusyjny -sukces-orbana-wyniki-referendum-migracyjnego-na-wegrzech [access: 11.11.2018].

${ }^{35}$ Article 8 section 4 of the Hungarian Constitution of 11 April 2011, http://libr.sejm.gov.pl/ tek01/txt/konst/wegry2013.pdf [access: 11.11.2018].

${ }^{36}$ A. Sadecki, Dyskusyjny sukces Orbána...

${ }^{37}$ Ibidem. 
"public enemy", and the institutions linked to him were accused of promoting liberal values and favouring immigration ${ }^{38}$.

Within the party there was a cooling of relations between Orbán and Simicska, who for many years was responsible for the party's finances. From 1990s onward, Simicska created a financial empire, and part of its profits was used to finance party's activities. He also stood behind the acquisition of opposition media and transforming them into a propaganda tube of the ruling Fidesz after 2010. The relaxed relations between the prime minister and L. Simcard meant that Orbán had to search for new sources of party funding.

In the political scene, Fidesz also had to be careful not to be identified with the overly radical Jobbik attitude, because that could trigger the outflow of a significant part of the electorate. It was challenging, as both parties are similar to each other in many different aspects. Hence, Fidesz consistently applied the policy of isolating Jobbik. In relation to the left, the party of Orbán had an easier task, because despite attempts to unify it, the tendency for its division prevails.

\section{Confirmation of domination: 2018}

The next elections to the National Assembly in Hungary took place on 8 April 2018 with a turnout of $66.68 \%$, the highest since $2006^{39}$. Once again the winner of the elections was Fidesz, which regained the constitutional majority of two-thirds of the seats it previously lost in the supplementary elections in two single-mandate constituencies in 2015 , mainly due to a mixed electoral system with a strong majority component (106 elected MPs in the first round, 93 from national party lists in a proportional system). This system favours the winner (with the support of $49 \%$ of voters, the party of Orbán won $67 \%$ of seats). Four opposition parties also joined the parliament: Jobbik (25 seats), the electoral coalition of the Hungarian Socialist Party and the Dialogue for Hungary (Hungarian: Párbeszéd Magyarországért, PM) (20 seats), Politics Can Be Different (8 seats) and the leftist Democratic Coalition (Hungarian: Demokratikus Koalíció, DK) of former Prime Minister Ferenc Gyurcsány (9 seats). One mandate from single-mandate constituencies each was won by the leftist Together Party, a representative of the German minority, and an independent candidate.

${ }^{38}$ A. Sadecki, Wegry: kampania przeciw Sorosowi, Analizy OSW, 5.04.2017, https://www.osw. waw.pl/pl/publikacje/analizy/2017-04-05/wegry-kampania-przeciw-sorosowi [access: 22.11.2018].

${ }^{39}$ Hungarian Election Office, http://www.valasztas.hu/en/ogy2018 [access: 22.11.2018]; A. Sadecki, Wybory na Wegrzech:... 
As Fidesz has a consolidated electorate of about 2 out of 8 million eligible to vote, and opposition votes are divided into several smaller opposition parties, this allows for domination, especially in single-mandate constituencies, where the party won as many as 91 out of 106 seats. In addition, as in the previous elections, the rights to vote on the party lists were given to Hungarians living abroad, mainly from Romania and Serbia, where Fidesz led an intense electoral campaign (380 thousand Hungarians living abroad registered for elections, and the percentage of Fidesz voters in this group amounted to over $90 \%)^{40}$.

Table 3. The results of the 2018 National Assembly elections in Hungary

\begin{tabular}{|c|c|c|c|c|c|c|}
\hline \multirow{2}{*}{ Political parties } & $\begin{array}{l}\text { Single-member } \\
\text { constituencies }\end{array}$ & \multicolumn{3}{|c|}{ The national list } & \multicolumn{2}{|r|}{ Total } \\
\hline & Seats & votes & $\begin{array}{l}\text { percentage } \\
\text { of votes }\end{array}$ & seats & seats & $\begin{array}{l}\text { percentage } \\
\text { share of seats }\end{array}$ \\
\hline Fidesz-KDNP & 91 & $2,824,551$ & 49.27 & 42 & 133 & 66.83 \\
\hline Jobbik & 1 & $1,092,806$ & 19.06 & 25 & 26 & 13.07 \\
\hline MSZP-Párbeszéd ${ }^{41}$ & 8 & 682,701 & 11.91 & 12 & 20 & 10.05 \\
\hline $\mathrm{LMP}^{42}$ & 1 & 404,429 & 7.06 & 7 & 8 & 4.02 \\
\hline $\mathrm{DK}^{43}$ & 3 & 308,161 & 5.38 & 6 & 9 & 4.52 \\
\hline Független ${ }^{44}$ & 1 & - & - & 0 & 1 & 0.05 \\
\hline Együtt ${ }^{45}$ & 1 & 36,561 & 0.66 & 0 & 1 & 0.05 \\
\hline $\mathrm{MNOO}^{46}$ & 0 & 26,477 & 0.46 & 1 & 1 & 0.05 \\
\hline Other parties & 0 & 414,746 & 6.20 & 0 & 0 & 1.36 \\
\hline Total & 106 & $5,791,432$ & 100 & 93 & 199 & 100 \\
\hline
\end{tabular}

Source: Authors' own elaboration based on Hungarian Election Office, http://valasztas.hu/en/ovi/index. html\#, http://www.valasztas.hu/en/ogy2018 [access: 15.11.2018].

The third consecutive and overwhelming Fidesz victory in the parliamentary elections confirmed the party's dominance on the Hungarian political scene. This is the merit and personal success of the leader of the single-leader style party, Viktor Orbán, who for the fourth time took office as prime minister. It is worth recalling that only in the years 2000-2003, he did not hold the office of Fidesz chairman, which was part of an attempt not to hold it jointly with the PM

\footnotetext{
${ }^{40}$ Ibidem.

${ }^{41}$ Hungarian Socialist Party - Dialogue for Hungary.

${ }^{42}$ Politics Can Be Different.

${ }^{43}$ DK-Democratic Coalition.

${ }^{44}$ Independent.

${ }^{45}$ Together.

${ }^{46}$ Self-Government of Germans in Hungary.
} 
position. In 2000, a trusted friend of Prime Minister László Kövér became the chairman, replaced a year later by Zoltán Pokorni, and in 2002 - by János Áder ${ }^{47}$.

The Fidesz election campaign focused mainly on anti-migration slogans that successfully consolidate the right-wing electorate (the government regularly organized billboards and media campaigns, and conducted the so-called national consultations several times), and a significant role in sustaining the topic of migration and the resulting threats to Hungary was played by public media, where Fidesz has a dominant position (in the last four years, businessmen affiliated with Fidesz bought, among others, all regional dailies in Hungary and one of the two largest commercial television channels, while the largest opposition newspaper in Hungary was shut down $)^{48}$. In addition, the government of Orbán presented itself as a defender of Hungarian sovereignty in the face of foreign pressure from the European Union, also warning against the influence of the American billionaire George Soros, who according to the government, pays the activities of opposition parties and non-governmental organizations. In June 2018, the Hungarian Parliament passed amendments to the law described by Fidesz as the "stop Soros" package ${ }^{49}$, which introduced a number of restrictions on non-governmental organizations, and the amendment of the penal code now states that "unlawful help for immigrants" is punishable by up to one year in prison ${ }^{50}$.

In this way, Fidesz skillfully uses the external threat to create a sense of fear and threat of the danger associated with the loss of sovereignty by Hungary, indicating that only the party is able to deal with it.

\section{Conclusions}

Responding to the first of the questions raised in the introduction (how Orbán and his party managed to succeed in the 2010 elections), it must be said that at least two factors have been used. First, it was a skillful reaction to the social-liberal coalition after the outbreak of the 2006 scandal. Fidesz remained in total opposition, presenting itself as a party of moral renewal. Secondly, it successfully carried out the process of consolidation of right-wing circles, avoiding the fragmentation of the right-wing electorate and successfully won the support of those citizens, who were disappointed by the Hungarian left.

${ }^{47}$ Fidesz, http://theorangefiles.hu/the-orban-regime/ [access: 30.09.2015].

${ }^{48}$ A. Sadecki, Wybory na Wegrzech...

${ }^{49}$ A. Sadecki, Wegry: pakiet przepisów antyimigracyjnych „Stop Soros”, Analizy OSW, 27.06.2018, https://www.osw.waw.pl/pl/publikacje/analizy/2018-06-27/wegry-pakiet-przepisow-antyimigracyjnych-stop-soros [access: 22.11.2018].

${ }^{50}$ Ibidem. 
Answering the second question raised in the introduction (which mechanisms used by Fidesz were used between 2010-2018 to maintain power) it should be noted that since Fidesz took power in 2010, Prime Minister Viktor Orbán's party had a sufficient majority in the Hungarian parliament in the subsequent years to implement a reform program covering the most important areas of political, social and economic life, serving the consolidation of power in the state. These changes meant the adoption of a new constitution of Hungary in 2011 and then the adoption of the entire package of bills, including media law, new electoral law and filling the most important positions in the country with Fidesz people. Undertaking such activities was connected with experiences drawn from the first Fidesz government (1998-2002), when they already attempted, albeit with no success, to introduce some of the changes introduced after 2010. Third in a row (in 2010, 2014 and 2018) Fidesz's overwhelming victory in the parliamentary elections confirmed the party's dominance on the Hungarian political scene, with a weak opposition that is neither a threat nor an alternative to Orbán's rule.

The Prime Minister thus used recent years to consolidate and develop his position and political rhetoric on the basis of three main tasks for the state: counteracting migration, counteracting the "dictate of Brussels" and fighting the "Soros empire". The thesis of the article on the skillful use of legal and propaganda measures by Fidesz in 2010-2018 in order to maintain power is thus confirmed. A package of legal changes made under the rule of Fidesz, skillful management of anti-migratory social moods, thanks to which the ruling party mobilizes its electorate by creating an atmosphere of foreign threat and the domination of Fidesz in the media market allows this party to maintain power in its hands. 


\section{Bibliography}

- Barański M., Czyż A., Kubas S., Rajczyk R., Wybory, prawo wyborcze, systemy wyborcze w państwach Grupy Wyszehradzkiej, Wydawnictwo Uniwersytetu Śląskiego, Katowice 2016.

- Chmaj M., Sokół W., Żmigrodzki M., Teoria partii politycznych, Wydawnictwo Morpol, Lublin 1999.

- Constitution of Hungary, http://libr.sejm.gov.pl/tek01/txt/konst/wegry2013.pdf [access: 11.11.2018].

- Debreczeni J., Viktor Orbán. Jeden obóz, jeden sztandar, jeden wódz, Wydawnictwo Akurat, Warszawa 2015.

- Enyedi Z., The Role of Agency in Cleavage Formation, "European Journal of Political Research" 2005, Vol. 44(5).

- Glied V., From a Green Movement to a Party. The Effect of the Crisis and Democratic Movements in Hungary, "Politeja" 2014, No. 28.

- Gniazdowski M., Jarosiewicz M., Wegierska odsłona kryzysu migracyjnego, Analizy OSW, 9.09.2015, https://www.osw.waw.pl/pl/publikacje/analizy/2015-09-09/wegierska-odslona-kryzysu-migracyjnego [access: 3.11.2018].

- Grotz F., Hubai L., Hungary, [in:] Elections in Europe. A Data Book, eds. D. Nohlen, P. Stöver, Nomos, Baden-Baden 2010.

- Herbut R., Teoria i praktyka funkcjonowania partii politycznych, Wydawnictwo Uniwersytetu Wrocławskiego, Wrocław 2002.

- Hungarian Election Office, http://www.valasztas.hu/en/parval2010/298/298_0_index. html [access: 9.02.2016].

- Hungarian Election Office, http://www.valasztas.hu/dyn/pv14/szavossz/en/orszlist_e. html [access: 15.11.2018].

- Hungarian Election Office, http://valasztas.hu/en/ovi/index.html\# [access: 15.11.2018].

- Hungarian Election Office, http://www.valasztas.hu/dyn/pv14/szavossz/en/napind_e. html [access: 22.11.2018].

- Hungarian Election Office, http://www.valasztas.hu/en/ogy2018 [access: 22.11.2018].

- Kubas S., Negacja dorobku i zdobyczy węgierskiej demokratyzacji po 2010 roku, „Studia Politologiczne", 2018, Vol. 47.

- Kubas S., Sukcesy wyborcze Fidesz-MSP i ich wptyw na konsolidacje prawicowych rząów na Węgrzech, [in:] Polskie wybory 2014-2015. Kontekst krajowy i międzynarodowy: przebieg rywalizacji, konsekwencje polityczne, t. 2, red. M. Kolczyński, Wydawnictwo Uniwersytetu Śląskiego, Katowice 2017.

- Kubas S., Zmiany w prawie wyborczym w kontekście przeobrażeń ustrojowych na Wegrzech po 2011 roku, „Przegląd Politologiczny” 2017, nr 1.

- Nemzeti Választási Iroda. Országgyülési választások Magyarországon, 2010, http:// www.valasztas.hu/en/parval2010/index.html [access: 9.11.2018].

- NSD. European Election Database. Hungary: Parliamentary Elections, 2010, http:// eed.nsd.uib.no/webview/index.jsp?study=http://129.177.90.166:80/obj/fStudy/ 
HUPA1990_Display\&mode=cube\&v=2\&cube=http://129.177.90.166:80/obj/fCube/ HUPA1990_Display_C1\&top=yes [access: 9.02.2016].

- Podolak M., Instytucja referendum w wybranych państwach Europy Środkowej $i$ Wschodniej (1989-2012), Wydawnictwo Uniwersytetu Marii Curie-Skłodowskiej, Lublin 2014.

- Ripp Z., Unity and Division. The Opposition Roundtable and its Relation to the Communist Party, [in:] The Roundtable Talks of 1989: The Genesis of Hungarian Democracy, ed. A. Bozóki, Central European University Press, Budapest 2002.

- Rytkó E., National Referenda in Hungary, http://www.aceeeo.org/sites/default/files/ PDF/presentation_of_conference/2008/Referenda\%20in\%20Hungary_english.pdf [access: 20.11.2015].

- Sadecki A., Dyskusyjny sukces Orbána - wyniki referendum migracyjnego na Wegrzech, Analizy OSW, 4.10.2016, https://www.osw.waw.pl/pl/publikacje/analizy/2016-10-04/ dyskusyjny-sukces-orbana-wyniki-referendum-migracyjnego-na-wegrzech [access: 11.11.2018].

- Sadecki A., Państwo stanu wyższej konieczności. Jak Orbán zmienit Wegry, „Punkt Widzenia" 2014, nr 41.

- Sadecki A., Węrry domknęty granicę z Serbią, Analizy OSW, 16.09.2015 https://www. osw.waw.pl/pl/publikacje/analizy/2015-09-16/wegry-domknely-granice-z-serbia [access: 11.11.2018].

- Sadecki A., Węry Orbána: konstytucyjna konsolidacja władzy, Analizy OSW, 4.01.2012, https://www.osw.waw.pl/pl/publikacje/analizy/2012-01-04/wegry-orbana-konstytucyjna-konsolidacja-wladzy [access: 22.11.2018].

- Sadecki A., Wegry: kampania przeciw Sorosowi, Analizy OSW, 5.04.2017, https://www. osw.waw.pl/pl/publikacje/analizy/2017-04-05/wegry-kampania-przeciw-sorosowi [access: 22.11.2018].

- Sadecki A., Wegry: pakiet przepisów antyimigracyjnych „Stop Soros”, Analizy OSW, 27.06.2018, https://www.osw.waw.pl/pl/publikacje/analizy/2018-06-27/wegry-pakiet -przepisow-antyimigracyjnych-stop-soros [access: 22.11.2018].

- Sadecki A., Wybory na Węrzech: potwierdzenie dominacji Viktora Orbána, Analizy OSW, 11.04.2018, https://www.osw.waw.pl/pl/publikacje/analizy/2018-04-11/wybory-na-wegrzech-potwierdzenie-dominacji-viktora-orbana [access: 22.11.2018].

- Sobolewski M., Partie i systemy partyjne świata kapitalistycznego, Państwowe Wydawnictwo Naukowe, Warszawa 1977.

- System Wspótpracy Narodowej, http://jezwegierski.blox.pl/2010/07/System-Wspolpracy-Narodowej.html [access: 21.11.2018].

- Századvég public opinion research centre, https://szazadveg.hu/hu [access: 15.11.2015].

- Tárki public opinion research centre, https://www.tarki.hu/ [access: 15.11.2018].

- Węgierskie Biuro Wyborcze, http://www.valasztas.hu/en/ogy2018 [access: 15.11.2018].

- Wegry. Fidesz zdobywa nowe media publiczne, Analizy OSW, http://www.osw.waw. $\mathrm{pl} / \mathrm{pl} /$ publikacje/ [access: 13.04.2012]. 
Summary: The article presents the development of Fidesz as a party which has been existing for three decades (1988-2018), yet the authors focus on the analysis of last eight years when Fidesz consequently has won three parliamentary elections. Fidesz turned from youth and liberal party in the mid-1990s to a conservative one which let it win elections in 1998. The article explains further activities of Fidesz to win elections in 2010, 2014 and 2018.

Keywords: Hungary; Fidesz; Viktor Orbán

Od liberalnej partii opozycyjnej do prawicowej partii władzy. Trzy dekady węgierskiego Fideszu (1988-2018)

Streszczenie: Artykuł dotyczy rozwoju węgierskiej partii Fidesz w kontekście trzech dekad jej istnienia (1988-2018). Autorzy skupili się na przeprowadzeniu analizy ostatnich ośmiu lat jej działalności, ponieważ w tym okresie partia nieprzerwanie wygrywała kolejne wybory parlamentarne. Ukazano fenomen Fideszu, który z ugrupowania o proweniencji liberalnej i młodzieżowej przekształcił się w silną organizację konsolidującą środowiska prawicowe. Ponadto wyjaśniono mechanizmy oraz przybliżono efekty działań podjętych przez partię Viktora Orbána w celu utrzymania władzy na Węgrzech.

Słowa kluczowe: Węgry; Fidesz; Viktor Orbán 